\title{
Roseomonas terrae sp. nov.
}

\author{
Jung-Hoon Yoon, So-Jung Kang, Hyun Woo Oh and Tae-Kwang Oh
}

Correspondence

Jung-Hoon Yoon

jhyoon@kribb.re.kr

\author{
Korea Research Institute of Bioscience and Biotechnology (KRIBB), PO Box 115, Yusong, \\ Taejon, Korea
}

\begin{abstract}
A Gram-negative, non-motile, coccobacilli-shaped bacterium, DS-48 ${ }^{\top}$, was isolated from soil from Dokdo, Korea, and its taxonomic position was investigated by means of a polyphasic study. Strain DS-48 ${ }^{\top}$ grew optimally at $25{ }^{\circ} \mathrm{C}$ and $\mathrm{pH} 7.0-8.0$ in the presence of $0.5 \%(\mathrm{w} / \mathrm{v}) \mathrm{NaCl}$. It contained $\mathrm{Q}-10$ as the predominant ubiquinone and $\mathrm{C}_{18: 1} \omega 7 \mathrm{c}$ and $\mathrm{C}_{18: 1} 2-\mathrm{OH}$ as the major fatty acids. The DNA G+C content was 69.3 mol\%. A phylogenetic analysis based on $16 \mathrm{~S}$ rRNA gene sequences showed that strain $\mathrm{DS}-48^{\top}$ fell within the genus Roseomonas, clustering with Roseomonas lacus $\mathrm{TH}-\mathrm{G} 33^{\top}$ (at a bootstrap confidence level of $100 \%$ ). The levels of similarity between the 16S rRNA gene sequence of strain DS-48 ${ }^{\top}$ and those of the type strains of recognized Roseomonas species were in the range 93.2-98.0\%. DNA-DNA relatedness data and differential phenotypic properties, together with the phylogenetic distinctiveness of DS $-48^{\top}$, revealed that this strain differs from recognized Roseomonas species. On the basis of phenotypic, phylogenetic and genetic data, therefore, strain $D S-48^{\top}$ represents a novel species within the genus Roseomonas, for which the name Roseomonas terrae sp. nov. is proposed. The type strain is DS $-48^{\top}\left(=\right.$ KCTC $\left.12874^{\top}=J C M 14592^{\top}\right)$.
\end{abstract}

The genus Roseomonas was erected by Rihs et al. (1993) with the description of three novel species, Roseomonas gilardii, Roseomonas cervicalis and Roseomonas fauriae, and three unnamed genomospecies. Recently, R. fauriae was reclassified as a later heterotypic synonym of Azospirillum brasilense (Helsel et al., 2006). At the time of writing, the genus comprises five Roseomonas species with validly published names: R. gilardii (Rihs et al., 1993; Han et al., 2003), R. cervicalis (Rihs et al., 1993), Roseomonas mucosa (Han et al., 2003), Roseomonas lacus (Jiang et al., 2006) and Roseomonas aquatica (Gallego et al., 2006). A phylogenetic analysis based on 16S rRNA gene sequences showed that the genus Roseomonas falls within the Alphaproteobacteria (Gallego et al., 2006). Here, we report on the taxonomic characterization of a Roseomonas-like bacterial strain, DS$48^{\mathrm{T}}$, which was isolated from soil from Dokdo, Korea.

Strain DS $-48^{\mathrm{T}}$ was isolated from a soil sample collected from Dokdo ( $\left.37^{\circ} 14^{\prime} 12^{\prime \prime} \mathrm{N}, 131^{\circ} 52^{\prime} 07^{\prime \prime} \mathrm{E}\right)$, an island of Korea, using the standard dilution plating technique at $25{ }^{\circ} \mathrm{C}$ on $10 \times$ diluted nutrient agar (NA; Difco). $R$. aquatica JCM $13556^{\mathrm{T}}$ and $R$. lacus JCM $13283^{\mathrm{T}}$, which were used as reference strains for phenotypic characterization, were obtained from the Japan Collection of Microorganisms, Saitama, Japan. The morphological, physiological and biochemical characteristics of strain $\mathrm{DS}-48^{\mathrm{T}}$ were

The GenBank/EMBL/DDBJ accession number for the 16S rRNA gene sequence of strain DS-48 ${ }^{\top}$ is EF363716.

A table showing phenotypic characteristics of strain DS- $48^{\top}$ and Roseomonas species is available with the online version of this paper. investigated using routine cultivation on $2 \times$ diluted NA at $25{ }^{\circ} \mathrm{C}$. The cell morphology was examined by using light microscopy (E600; Nikon) and transmission electron microscopy. Flagellation was determined by using a Philips CM-20 transmission electron microscope with cells from exponentially growing cultures: for this purpose, the cells were negatively stained with $1 \%$ (w/v) phosphotungstic acid and the grids were examined after being air-dried. The Gram reaction was determined by using the bioMérieux Gram stain kit according to the manufacturer's instructions. Growth at various temperatures $\left(4-40{ }^{\circ} \mathrm{C}\right)$ was determined on $2 \times$ diluted NA. Growth in the absence of $\mathrm{NaCl}$ and at various $\mathrm{NaCl}$ concentrations [0.5 and 1.0$5.0 \%,(\mathrm{w} / \mathrm{v})$ using increments of $1.0 \%$ ] was investigated in trypticase soy broth prepared according to the formula of the Difco medium except that $\mathrm{NaCl}$ was excluded. The $\mathrm{pH}$ range for growth was determined in $2 \times$ diluted nutrient broth (Difco) that had been adjusted to various $\mathrm{pH}$ values ( $\mathrm{pH} 4.5-10.5$, using increments of $0.5 \mathrm{pH}$ units), prior to sterilization, by the addition of $\mathrm{HCl}$ or $\mathrm{Na}_{2} \mathrm{CO}_{3}$. Growth under anaerobic conditions was determined after incubation in an anaerobic chamber on $2 \times$ diluted NA and on $2 \times$ diluted NA supplemented with nitrate, both of which had been prepared anaerobically using nitrogen. Catalase and oxidase activities and the hydrolysis of casein, gelatin, hypoxanthine, starch, Tweens 20, 40, 60 and 80, tyrosine, urea and xanthine were determined as described by Cowan \& Steel (1965). Aesculin hydrolysis and nitrate reduction were studied as described previously (Lanyi, 1987). Antibiotic susceptibility was tested on $2 \times$ diluted NA plates using antibiotic discs containing the following 
concentrations ( $\mu \mathrm{g}$ unless indicated otherwise); $100 \mathrm{U}$ polymyxin B, 50 streptomycin, $20 \mathrm{U}$ penicillin $\mathrm{G}, 100$ chloramphenicol, 10 ampicillin, 30 cephalothin, 30 gentamicin, 5 novobiocin, 30 tetracycline, 30 kanamycin, 15 lincomycin, 15 oleandomycin, 30 neomycin, 100 carbenicillin. Substrate utilization, enzyme activities and other physiological and biochemical properties were tested by using the API 50CH, API ZYM, API 20E and API 20NE systems (bioMérieux); the utilization of various substrates was determined by inoculating the API $50 \mathrm{CH}$ strip with cells suspended in AUX medium (bioMérieux).

Cell biomass for DNA extraction and for isoprenoid quinone analysis was obtained from cultivation in $2 \times$ diluted nutrient broth at $25{ }^{\circ} \mathrm{C}$. Chromosomal DNA was isolated and purified according to the method described by Yoon et al. (1996), except that RNase T1 was used in combination with RNase A to minimize contamination from RNA. The 16S rRNA gene was amplified by using a PCR with two universal primers, as described previously (Yoon et al., 1998). Sequencing of the amplified 16S rRNA gene and phylogenetic analysis were performed as described by Yoon et al. (2003). Isoprenoid quinones were extracted according to the method of Komagata \& Suzuki (1987) and analysed using reversed-phase HPLC with a YMC ODS-A $(250 \times 4.6 \mathrm{~mm})$ column. For fatty acid methyl ester analysis, cell mass of strain $\mathrm{DS}-48^{\mathrm{T}}$ was harvested from $2 \times$ diluted NA plates after incubation for 7 days at $25{ }^{\circ} \mathrm{C}$. The fatty acids were extracted and fatty acid methyl esters prepared according to the standard protocol of the MIDI/Hewlett Packard Microbial Identification System (Sasser, 1990). The DNA G+C content was determined using the method of Tamaoka \& Komagata (1984), with the modification that the DNA was hydrolysed and the resultant nucleotides analysed by reversed-phase HPLC. DNA-DNA hybridization was performed fluorometrically according to the method of Ezaki et al. (1989) using photobiotin-labelled DNA probes and microdilution wells. Hybridization was performed with five replications for each sample: the highest and lowest values obtained for each sample were excluded and the means of the remaining three values were quoted as the DNA-DNA relatedness values.

Morphological, cultural, physiological and biochemical characteristics of strain DS- $48^{\mathrm{T}}$ are given in the species description (see below) or are shown in Table 1 (see also Supplementary Table S1 available in IJSEM Online). The almost-complete $16 \mathrm{~S}$ rRNA gene sequence of strain DS- $48^{\mathrm{T}}$ determined in this study comprised 1442 nt (representing approx. $96 \%$ of the Escherichia coli 16S rRNA gene sequence). Comparative $16 \mathrm{~S}$ rRNA gene sequence analyses showed that strain DS- $48^{\mathrm{T}}$ was most closely related phylogenetically to the genus Roseomonas within the Alphaproteobacteria (Fig. 1). In the neighbour-joining tree based on 16S rRNA gene sequences, strain DS- $48^{\mathrm{T}}$ fell within the cluster comprising Roseomonas species, clustering with $R$. lacus $\mathrm{TH}-\mathrm{G} 33^{\mathrm{T}}$ at a bootstrap confidence level of $100 \%$ (Fig. 1). Strain DS- $48^{\mathrm{T}}$ exhibited $98.0 \% 16 \mathrm{~S}$
rRNA gene sequence similarity with respect to R. lacus TH$\mathrm{G}_{3} 3^{\mathrm{T}}$ and $93.2-94.3 \%$ similarity with respect to the type strains of the other Roseomonas species. The sequence similarity values with respect to other species used in the phylogenetic analysis were below $93.7 \%$.

Strain DS- $48^{\mathrm{T}}$ contained Q-10, at a peak area ratio of approximately $90 \%$, as the predominant isoprenoid quinone; minor amounts of Q-7 and Q-11 were present. $R$. lacus and $R$. aquatica were reported to have Q-10 as predominant ubiquinone (Jiang et al., 2006; Gallego et al., 2006). The fatty acid profile of strain DS- $48^{\mathrm{T}}$ was composed of the following (each constituting $>0.5 \%$ of total fatty acids): unsaturated fatty acids $\mathrm{C}_{18: 1} \omega 7 c$ $(63.9 \%), \quad \mathrm{C}_{16: 1} \omega 5 c \quad(3.9 \%), \quad \mathrm{C}_{17: 1} \omega 7 c \quad(1.2 \%)$ and $\mathrm{C}_{18: 1} \omega 5 c(0.6 \%)$; hydroxyl fatty acids $\mathrm{C}_{18: 1} 2-\mathrm{OH}$ $(10.3 \%), \mathrm{C}_{16: 0} 3-\mathrm{OH}(1.4 \%), \mathrm{C}_{16: 0} 2-\mathrm{OH}(1.1 \%)$ and $\mathrm{C}_{18: 0} 3-\mathrm{OH}(0.5 \%)$; straight-chain fatty acid $\mathrm{C}_{16: 0}(8.8 \%)$; cyclo fatty acid $\mathrm{C}_{19: 0}$ cyclo $\omega 8 c(5.2 \%)$; summed feature 3 $\left(\mathrm{C}_{16: 1} \omega 7 c\right.$ and/or iso- $\left.\mathrm{C}_{15: 0} 2-\mathrm{OH}, 1.3 \%\right)$; branched fatty acid iso- $\mathrm{C}_{17: 0} 3-\mathrm{OH}(0.9 \%)$; and summed feature 2 (iso$\mathrm{C}_{16: 1}, \mathrm{C}_{14: 0} 3-\mathrm{OH}$ and/or an unknown fatty acid with an equivalent chain length of $10.928,0.6 \%)$. This fatty acid profile was similar to those of Roseomonas species, although there were differences with respect to $R$. lacus, perhaps resulting from differences in the cultivation conditions (Han et al., 2003; Jiang et al., 2006; Gallego et al., 2006). The DNA G $+C$ content of strain DS- $48^{\mathrm{T}}$ was $69.3 \mathrm{~mol} \%$. These chemotaxonomic properties were in agreement with the result of the phylogenetic classification, i.e. that strain DS- $48^{\mathrm{T}}$ belongs to the genus Roseomonas (Han et al., 2003; Jiang et al., 2006; Gallego et al., 2006).

Strain DS- $48^{\mathrm{T}}$ exhibited a mean DNA-DNA relatedness value of $17 \%$ with respect to $R$. lacus $\mathrm{TH}-\mathrm{G} 33^{\mathrm{T}}$, showing a $16 \mathrm{~S}$ rRNA gene sequence similarity value of greater than $97 \%$. Strain DS- $48^{\mathrm{T}}$ is distinguishable from Roseomonas species through differences in several phenotypic characteristics (Table 1 and Supplementary Table S1). The phylogenetic distinctiveness of DS- $48^{\mathrm{T}}$, the DNA-DNA relatedness data and the differential phenotypic properties are sufficient to show that this strain is distinct from the recognized Roseomonas species (Wayne et al., 1987; Stackebrandt \& Goebel, 1994). Therefore, on the basis of the data presented, strain DS- $48^{\mathrm{T}}$ represents a novel species of the genus Roseomonas, for which the name Roseomonas terrae sp. nov. is proposed.

\section{Description of Roseomonas terrae sp. nov.}

Roseomonas terrae (ter'rae. L. gen. n. terrae of the soil).

Cells are Gram-negative, non-spore-forming coccobacilli $(0.6-0.9 \times 0.6-3.0 \mu \mathrm{m})$. Colonies on $2 \times$ diluted NA are circular, convex, smooth, glistening, pale yellow to pale pink in colour and $0.5-0.8 \mathrm{~mm}$ in diameter after incubation for 7 days at $25{ }^{\circ} \mathrm{C}$. Optimal growth occurs at $25^{\circ} \mathrm{C}$; growth occurs weakly at 10 and $36{ }^{\circ} \mathrm{C}$, but not at 4 or $37^{\circ} \mathrm{C}$. Optimal pH for growth is between 7.0 and 8.0; growth occurs at pH 5.5 and 10.5, but not at pH 5.0 or 
Table 1. Differential phenotypic characteristics (determined in this study) for strain $D S-48^{\top}$ and phylogenetically related Roseomonas species

Strains: $1, \mathrm{DS}-48^{\mathrm{T}} ; 2$, R. lacus; 3, R. aquatica. All of the strains are positive for catalase, oxidase, alkaline phosphatase, esterase (C4) and esterase lipase (C8) and for susceptibility to chloramphenicol, gentamicin, kanamycin, streptomycin and tetracycline. All of the strains are negative for the following: motility [data for $R$. lacus and R. aquatica from Jiang et al. (2006) and Gallego et al. (2006), respectively]; hydrolysis of aesculin, casein, hypoxanthine, xanthine, starch, tyrosine, gelatin and Tween 80; utilization of glycerol, erythritol, adonitol, methyl $\beta$-D-xyloside, glucose, fructose, mannose, sorbose, rhamnose, dulcitol, inositol, mannitol, sorbitol, methyl $\alpha$-D-glucoside, amygdalin, arbutin, aesculin, salicin, cellobiose, maltose, lactose, melibiose, sucrose, trehalose, inulin, melezitose, raffinose, starch, glycogen, xylitol, gentiobiose, D-turanose, D-tagatose, Darabitol and L-arabitol; arginine dihydrolase, lysine decarboxylase, ornithine decarboxylase, tryptophan deaminase, lipase (C14), leucine arylamidase, valine arylamidase, cystine arylamidase, trypsin, $\alpha$-chymotrypsin, $\alpha$-galactosidase, $\beta$-galactosidase, $\beta$-glucuronidase, $\alpha$-glucosidase, $\beta$-glucosidase, $N$-acetyl- $\beta$-glucosaminidase, $\alpha$ mannosidase and $\alpha$-fucosidase; and susceptibility to ampicillin, cephalothin, lincomycin, novobiocin, oleandomycin, penicillin G and polymyxin B. +, Positive reaction; -, negative reaction; w, weakly positive reaction.

\begin{tabular}{|c|c|c|c|}
\hline Characteristic & 1 & 2 & 3 \\
\hline Optimal growth temperature $\left({ }^{\circ} \mathrm{C}\right)$ & 25 & $30^{*}$ & $25-28 \dagger$ \\
\hline Maximum growth temperature $\left({ }^{\circ} \mathrm{C}\right)$ & 36 & $40^{*}$ & $35 \dagger$ \\
\hline Maximum $\mathrm{NaCl}$ concentration for growth (\%) & 1.0 & $6.5^{\star}$ & $<2.0 \dagger$ \\
\hline Nitrate reduction & - & + & - \\
\hline \multicolumn{4}{|l|}{ Hydrolysis of: } \\
\hline Tween 20 & + & - & + \\
\hline Tween 40 & - & - & + \\
\hline Tween 60 & - & - & + \\
\hline Urea & + & + & - \\
\hline \multicolumn{4}{|l|}{ Utilization of: } \\
\hline D-Arabinose & - & - & + \\
\hline L-Arabinose & - & - & + \\
\hline Ribose & - & - & + \\
\hline D-Xylose & - & - & + \\
\hline L-Xylose & - & - & + \\
\hline Galactose & - & - & + \\
\hline Methyl $\alpha$-D-mannoside & - & + & - \\
\hline D-Lyxose & - & - & + \\
\hline D-Fucose & - & - & + \\
\hline L-Fucose & - & - & + \\
\hline Gluconate & - & - & + \\
\hline 2-Ketogluconate & - & - & + \\
\hline 5-Ketogluconate & - & - & + \\
\hline Adipate & - & + & - \\
\hline Malate & - & + & + \\
\hline \multicolumn{4}{|l|}{ Enzyme activity (API ZYM) } \\
\hline Naphthol-AS-BI-phosphohydrolase & + & - & - \\
\hline Acid phosphatase & + & + & - \\
\hline \multicolumn{4}{|l|}{ Susceptibility to: } \\
\hline Carbenicillin & - & $\mathrm{w}$ & - \\
\hline Neomycin & + & + & $\mathrm{w}$ \\
\hline Isolation source & Soil & Freshwater-lake sediment & Drinking water \\
\hline DNA G $+C$ content $(\mathrm{mol} \%)$ & 69.3 & $71.9^{*}$ & $68.6 \dagger$ \\
\hline
\end{tabular}

${ }^{\star}$ Data for R. lacus from Jiang et al. (2006).

$\dagger$ Data for R. aquatica from Gallego et al. (2006).

11.0. Growth occurs in the presence of $0-1.0 \%(\mathrm{w} / \mathrm{v})$, with an optimum in the presence of $0.5 \%(\mathrm{w} / \mathrm{v}) \mathrm{NaCl}$. Growth does not occur under anaerobic conditions on $2 \times$ diluted
NA or on $2 \times$ diluted NA supplemented with nitrate. $\mathrm{H}_{2} \mathrm{~S}$ and indole are not produced. None of the substrates in the API 20NE and API 50CH strips is utilized as a sole carbon 


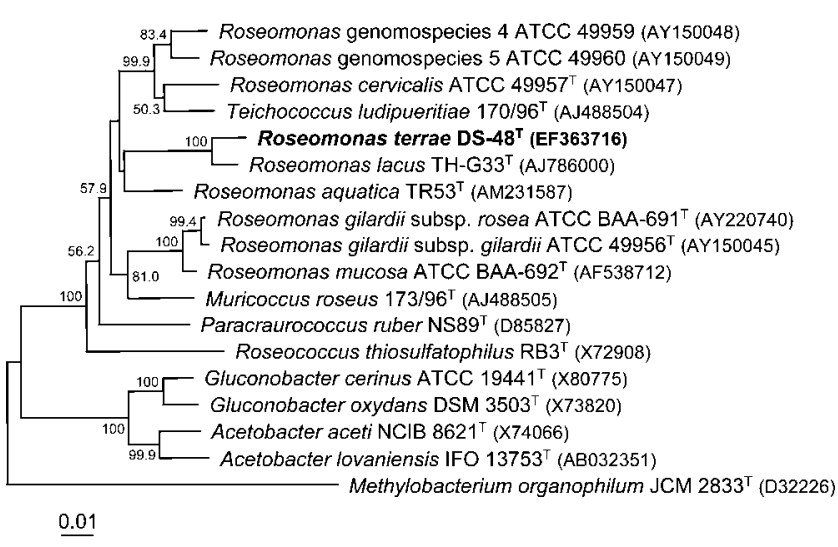

Fig. 1. Neighbour-joining phylogenetic tree, based on $16 \mathrm{~S}$ rRNA gene sequences, showing the positions of strain $D S-48^{\top}$ and some related taxa. Bootstrap percentages (based on 1000 replications) $\geqslant 50 \%$ are shown at the nodes. Methylobacterium organophilum JCM $2833^{\top}$ (GenBank accession number, D32226) was used as the outgroup. Bar, 0.01 substitutions per nucleotide position.

source. The predominant ubiquinone is Q-10. The major fatty acids $\left(>10 \%\right.$ of total fatty acids) are $\mathrm{C}_{18: 1} \omega 7 c$ $(63.9 \%)$ and $\mathrm{C}_{18: 1} 2-\mathrm{OH}(10.3 \%)$. The DNA $\mathrm{G}+\mathrm{C}$ content is $69.3 \mathrm{~mol} \%$ (HPLC). Other phenotypic properties are shown in Table 1 (see also Supplementary Table S1 available in IJSEM Online).

The type strain, DS $-48^{\mathrm{T}}\left(=\mathrm{KCTC} 12874^{\mathrm{T}}=\mathrm{JCM} 14592^{\mathrm{T}}\right)$, was isolated from soil from Dokdo in Korea.

\section{Acknowledgements}

This work was supported by the 21C Frontier Program of Microbial Genomics and Applications (grant MG05-0401-2-0) from the Ministry of Science and Technology (MOST) of the Republic of Korea.

\section{References}

Cowan, S. T. \& Steel, K. J. (1965). Manual for the Identification of Medical Bacteria. London: Cambridge University Press.

Ezaki, T., Hashimoto, Y. \& Yabuuchi, E. (1989). Fluorometric deoxyribonucleic acid-deoxyribonucleic acid hybridization in microdilution wells as an alternative to membrane filter hybridization in which radioisotopes are used to determine genetic relatedness among bacterial strains. Int J Syst Bacteriol 39, 224-229.

Gallego, V., Sánchez-Porro, C., García, M. T. \& Ventosa, A. (2006). Roseomonas aquatica sp. nov., isolated from drinking water. Int J Syst Evol Microbiol 56, 2291-2295.

Han, X. Y., Pham, A. S., Tarrand, J. J., Rolston, K. V., Helsel, L. O. \& Levett, P. N. (2003). Bacteriologic characterization of 36 strains of Roseomonas species and proposal of Roseomonas mucosa sp nov and Roseomonas gilardii subsp rosea subsp nov. Am J Clin Pathol 120, 256-264.

Helsel, L. O., Hollis, D. G., Steigerwalt, A. G. \& Levett, P. N. (2006). Reclassification of Roseomonas fauriae Rihs et al. 1998 as a later heterotypic synonym of Azospirillum brasilense Tarrand et al. 1979. Int J Syst Evol Microbiol 56, 2753-2755.

Jiang, C.-Y., Dai, X., Wang, B.-J., Zhou, Y.-G. \& Liu, S.-J. (2006). Roseomonas lacus sp. nov., isolated from freshwater lake sediment. Int J Syst Evol Microbiol 56, 25-28.

Komagata, K. \& Suzuki, K. (1987). Lipid and cell-wall analysis in bacterial systematics. Methods Microbiol 19, 161-207.

Lanyi, B. (1987). Classical and rapid identification methods for medically important bacteria. Methods Microbiol 19, 1-67.

Rihs, J. D., Brenner, D. J., Weaver, R. E., Steigerwalt, A. G., Hollis, D. G. \& Yu, V. L. (1993). Roseomonas, a new genus associated with bacteremia and other human infections. J Clin Microbiol 31, 3275-3283.

Sasser, M. (1990). Identification of Bacteria by Gas Chromatography of Cellular Fatty Acids, Technical Note 101. Newark, DE: MIDI.

Stackebrandt, E. \& Goebel, B. M. (1994). Taxonomic note: a place for DNA-DNA reassociation and $16 \mathrm{~S}$ rRNA sequence analysis in the present species definition in bacteriology. Int J Syst Bacteriol 44, 846-849.

Tamaoka, J. \& Komagata, K. (1984). Determination of DNA base composition by reversed-phase high-performance liquid chromatography. FEMS Microbiol Lett 25, 125-128.

Wayne, L. G., Brenner, D. J., Colwell, R. R., Grimont, P. A. D., Kandler, O., Krichevsky, M. I., Moore, L. H., Moore, W. E. C., Murray, R. G. E. \& other authors (1987). International Committee on Systematic Bacteriology. Report of the ad hoc committee on reconciliation of approaches to bacterial systematics. Int J Syst Bacteriol 37, 463-464.

Yoon, J.-H., Kim, H., Kim, S.-B., Kim, H.-J., Kim, W. Y., Lee, S. T., Goodfellow, M. \& Park, Y.-H. (1996). Identification of Saccharomonospora strains by the use of genomic DNA fragments and rRNA gene probes. Int J Syst Bacteriol 46, 502-505.

Yoon, J.-H., Lee, S. T. \& Park, Y.-H. (1998). Inter- and intraspecific phylogenetic analysis of the genus Nocardioides and related taxa based on 16S rRNA gene sequences. Int J Syst Bacteriol 48, 187-194.

Yoon, J.-H., Kim, I.-G., Shin, D.-Y., Kang, K. H. \& Park, Y.-H. (2003). Microbulbifer salipaludis sp. nov., a moderate halophile isolated from a Korean salt marsh. Int J Syst Evol Microbiol 53, 53-57. 